3. Для мети цієї статті термін "примусова чи обов'язкова праця" не включає: в) будь-яку працю військового характеру, а в тих країнах, в яких як законна визнається відмова від військової служби з релігійно-етичних мотивів, службу, яка призначається замість обов'язкової військової служби.

\title{
Стаття 9.
}

1. Кожна людина має право на свободу думки, совісті і релігії, це право включає свободу міняти свою релігію або переконання і свободу сповідувати свою релігію чи переконання як особисто, так і разом з іншими, публічно або приватно, в богослужінні, учінні чи відправі релігійних і ритуальних обрядів.

2. Свобода сповідувати свої релігію чи переконання підлягає лише таким обмеженням, які встановлені законом й необхідні в демократичному суспільстві в інтересах громадського спокою, охорони громадського порядку, здоров'я або моралі, а чи для захисту прав і свобод інших осіб.

\section{МІЖНАРОДНИЙ ПАКТ ПРО ГРОМАДЯНСЬКІ I ПОЛІТИЧНІ ПРАВА}

Прийнятий і відкритий для підписання, ратифікації і приєднання резолюцією 2200 A (XXI) Генеральної Асамблеї ООН 16.12.1966 р., вступив в силу 23.03.1976 p.

Стаття 18.

1. Кожна людина має право на свободу думки, совісті та релігії. Це право включає свободу мати або приймати релігію чи переконання згідно свого вибору і свободу сповідувати свою релігію і переконання як одноосібно, так і разом з іншими, публічно або приватно, у відправленні культу, виконанні релігійних і ритуальних обрядів і учень.

2. Ніхто не повинен поддаватися примусу, який обмежує його свободу мати або приймати релігію чи переконання за своїм вибором.

3. Свобода сповідувати релігію чи переконання може піддаватися лише таким обмеженням, які визначені законами і необхідні для охорони суспільної безпеки, порядку, здоров'я і моралі, водночас як і основних прав та свобод інших осіб.

4. Держави, які беруть участь в цьому Пакті, беруть зобов'язання поважати свободу батьків і у відповідних випадках законних опікунів забезпечувати релігійне і моральне виховання своїх дітей у відповідності із своїми власними переконаннями. 
Стаття 19.

1. Кожна людина має право безперешкодно дотримуватися своєї думки.

2. Кожна людина має право на вільне вираження своєї думки; це право включає свободу шукати, одержувати і поширювати всякого роду інформацію та ідеї, незалежно від державних кордонів, усно, письмово або через пресу чи художні форми вираження, або ж іншим способом вираження за своїм вибором.

3. Користування передбаченими в п.2 цієї статті правами накладає особливі зобов'язання і особливу відповідальність. Воно може бути, відтак, пов'язане з деякими обмеженнями, які, однак, повинні визначатися законом і бути необхідними: а) для поваги прав і репутації інших осіб; б) для охорони державної безпеки, громадського порядку, здоров'я чи моральності населення.

Стаття 20. 2. Всякий виступ на користь національної, расової або релігійної ненависті, який є підбурюванням до дискримінації, ворожнечі чи насилля, мусить заборонятися законом.

Стаття 27. У тих країнах, де існують етнічні, релігійні та мовні меншини, особам, які належать до таких меншин, не може бути відмовлено у праві разом з іншими членами тієї ж групи користуватися своєю культурою, сповідувати свою релігію і виконувати її обряди, а також користуватися рідною мовою.

\title{
ПІДСУМКОВИЙ АКТ НАРАДИ З БЕЗПЕКИ ТА СПІВРОБІТНИЦТВА В ЄВРОПI
}

\author{
Хельсинки, 30 липня - 1 серпня 1975 р.
}

а) Декларація принципів, якими держави-учасники будуть керуватися у взаємних відносинах

VII. Повага прав людини і основних свобод, включаючи свободу совісті, релігії і переконання. Держави-учасники будуть поважати право людини і основні свободи, включаючи свободу думки, совісті, релігії і переконання для всіх, без відмінності раси, статі, мови і релігії... В цих межах держави-учасники будуть визнавати і поважати свободу особи сповідувати, одноосібно або разом з іншими, релігію чи віру, діючи у відповідності з повелінням власної совісті. 